\title{
Literature as Conduct: On J. Hillis Miller's Speech-act Theory and Its Application
}

\author{
GUO RONG
}

\begin{abstract}
Since the publication of How to Do Things with Words in 1962, Austin and his speech-act theory caused a great disturbance in the arena of linguistics and literature, not only initiating the study of pragmatics but also triggering the paradigm change of literary studies in the $20^{\text {th }}$ century. Stanley Fish, Wolfgang Iser, Derrida, de Man, J. Hillis Miller, and many other scholars in the 1970s showed great enthusiasm for theory. Yet, the theory's limitations and applications are widely known. The publication of Speech Acts in Literature and Literature as Conduct by J. Hillis Miller seems to have given a kind of momentum to its development. Taking Miller's initiatives as a starting point, this article analyzes a specific literary text, The Ninth Widow by a Chinese overseas writer Yan Geling, with an intention to illustrate that the application of the speech-act theory in the literary studies is indeed promising and productive.
\end{abstract}

Keywords: speech-act; J. Hillis Miller; Yan Geling; The Ninth Widow

Literature is the art of language, and naturally the linguistic turn in the $20^{\text {th }}$ century had promoted greatly the paradigm change in literary studies. The speech-act theory, as a core of pragmatics, has witnessed the process of expansion and integration between linguistics and literature. Originally initiated by J. L. Austin in the mid-1950s, speech-act was once a buzzing word for Stanley Fish, Wolfgang Iser, Jacques Derrida, Paul de Man, J. Hillis Miller, and many other scholars in the 1970s. The introduction of speechact theory provides a seemingly promising battleground for literary studies, but its limitations and applications are widely known. In this essay, J. Hillis Miller's view of the speech-act in literature will be discussed in particular and a tentative application of speech-act theory in interpreting literary works will follow after.

Along with the publication of How to Do Things with Words in 1962, J. L. Austin and his speech-act theory caused a great disturbance in the academic circles of Europe and America. There is no doubt that this work is a revolutionary contribution to the development of pragmatics and linguistic 
GUO

philosophy. Unfortunately, Austin did not include literary language in his discussion. He asserts that a performative utterance will "be in a peculiar way hollow or void if said by an actor on the stage, or if introduced in a poem, or spoken in soliloquy" (Austin 1975: 22). For him, language in such circumstances is "in special ways - intelligibly - used not seriously, but in ways parasitic upon its normal use - ways which fall under the doctrine of the etiolations of language" (ibid.). Austin's general exclusion of literature from the realm of speech acts, in the words of J. Hillis Miller, "fails to recognize, according to de Man and Derrida, the many ways in which literature makes something happen, as well as the many ways in which nonliterature is infected by the literary" (Miller 2005: 8). For Austin and to some extent, John Searle, a speech act leaves intact the rules and conventions that enabled it, whereas for de Man and Derrida, each performative act, "even though it may repeat a form of words used perhaps innumerable times before, is radically singular and inaugural. It changes the rules and institutions themselves, as well as the surrounding context, rather than simply depending on them to get something efficiently done" (ibid.).

Undoubtedly, Iser also actively supports the application of speech act theory into the study of literary works. He writes in his book, The Act of Reading, that the pragmatic nature of language has been most clearly brought into focus by ordinary language philosophy, and that the concepts developed in this manner can nevertheless serve as a starting point for the study of the pragmatic nature of literary texts, though they are not meant to be applied to fictions (Iser 1978: 54). The concepts mentioned above refer to the speech-act theory. According to Iser, speech-act theory is an attempt, derived from ordinary language philosophy, to describe those factors that affect the success or failure of linguistic communication. These factors also "pertain to the reading of fiction, which is a linguistic action in the sense that it involves an understanding of the text, or of what the text seeks to convey, by establishing a relationship between text and reader" (ibid. 54-55). Iser points out that for the study of the pragmatic nature of literary texts, the illocutionary and perlocutionary speech acts are of particular interest (ibid. 57).

Iser's views of speech-act theory and the reading of fiction are echoed in Miller's book, Literature as Conduct. Miller writes, "Putting things in words is speech that acts. It does something that may do other things in its turn. It is a way of doing things with words" (Miller 2005: 2). He even identifies three forms of doing things with words in relation to literature as conduct: 
Literature as Conduct: On J. Hillis Miller's Speech-act Theory and Its Application

1) The author's act of writing, which is a doing that takes the form of putting things in this way or that; ${ }^{1}$

2) The narrators and characters in a work of fiction may utter speech acts that are a form of doing things with words, e.g. promises, declarations, excuses, denials, acts of bearing witness, lies, decisions publicly attested, and the like;

3) The reader, in his or her turn, in acts of teaching, criticism, or informal comment, may do things by putting a reading into words. Doing that may have an effect on students, readers, or acquaintances. Teaching, or writing criticism, or just talking about a book is a doing that may do other things in its turn. (Ibid.)

Considering this argument, it might be safe to say that, to some degree, the deconstructionist views of de Man and Derrida have greatly expanded the domain of speech act theory, and their perspectives have contributed to the application of speech act theory in literature. In this regard, Miller has set up a successful example. He has not only written a theoretical book, Speech Acts in Literature, but also practiced the speech act theory in his analysis of Henry James's novels.

Borrowing from Miller's idea that "the way literature may conduct its readers to believe or to behave in new way," we may explore the relations of literature to conduct by reading a certain literary work (ibid. 2). In other words, we can read literary works in the light of speech act theory. Unlike Miller, however, who mainly analyzes the speech acts of the narrators and characters, this article is going to focus on the act of the author's writing and my reading acts as a specific reader. For me, the writers, if they are serious about their career, may or may not state clearly their aims and their principles of writing, but they must have hidden between the lines their tenets or politics of writing. In this essay, the whole literary work will be taken as a performative speech act/utterance, in which the constative dimension is, for me, the story of the fictional world, and the performative dimension is what I am discussing about, the interpretive force of each work. Apparent constatives often work performatively. Hence, my analysis works on two levels: the constative level, the characters and narrators in the fictional world; and the performative level, the act of the author's writing. As Miller claims, the performative signs (including pictures, moving and still, as well as oral speech, written language, and music) masking as constative assertions generate what we call ideology (ibid. 7), I

1 Miller's claim about the author's act of writing seems to have been echoed in Rushdie's statement that "description is itself a political act" (Rushdie 1991: 13). 
GUO

would like to paraphrase this as follows: the fictional world masking as the imaginary world conveys/reveals the message of ideology. Miller also points out that reading a literary work confers a responsibility on the reader to make an accounting of his or her act of reading, for a reading, as he said above, is, to some degree, a doing that may do other things in its turn. I am now making an accounting of my reading act, and I hope my accounting will shed some light for the future reader on the novel, The Ninth Widow, by Yan Geling, a Chinese overseas writer residing mainly in the United States.

The appearance of The Ninth Widow inspired a great deal of critique in 2006 China. Some scholars highly commend it as one of the most important publications of contemporary Chinese literature (Chen Sihe 2006: 305), while some critics rebuke it sharply for the historical nihilism reflected in the novel (Zhou Shuitao 2006: 80). Both voices are representative, but I do not quite agree with either of them. Deeply touched by the female protagonist, who belongs to the generation of my parents, I began my journey of exploration.

During the turbulent years in the last century in China, when various political movements were launched and carried out intensively, the female protagonist, Wang Putao, was always criticized for possessing no political consciousness, but this comment did hold water. To a certain extent, the book is indeed about "the destiny of a particular individual" and my reading coincides with Fredric Jameson's proposition of the anagogical interpretation (Jameson 1981: 30-31).

For people who have finished middle school and college education in mainland China, Chinese history, especially the revolutionary history in the twentieth century, is a formalized and fixed framework of narratives. Owing to the publication and widespread distribution of the "red literary classics," such as Ding Ling's The Sun Shines over the Sanggan River (1952), Zhou Libo's The Hurricane (1956), Zhao Shuli's Three Mile Bay (1958) and Liu Qing's The Builders (1966), historical events such as the land reform campaign in the late 1940s, the subsequent cooperative transformation of agriculture, as well as the extreme years of the Great Leap Forward, have been resolved and settled.

Based on these narratives, the revolutionary actions and political movements launched by the Chinese Communist Party were forcibly supported by the ordinary grass-roots masses, especially the poor peasants, and carried through enthusiastically; and therefore, these movements are historically progressive and their revolutionary significance is justified and beyond any

2 “红色经典” a term used to describe the literary works produced according to the Chinese Communist Party policy about the political struggles or movements launched by the Party, particularly in the 1940s and 1950s. 
Literature as Conduct: On J. Hillis Miller's Speech-act Theory and Its Application

doubt. This kind of framework of narratives, that is, the master narratives, has influenced several generations in China, including those comparatively advanced members of the intellectual elite like the well-known contemporary writer, Chen Zhongshi, the author of White Deer Plain (1993), the winner of the 1998 Mao Dun Literary Reward. Chen had never doubted the credibility of the above-mentioned narratives, particularly Liu Qing's The Builders and Zhao Shuli's Three Mile Bay, until one evening in the spring of 1982 when he was transferred to assist and supervise the implementation of the policy: to divide and assign land to each household.

In The Ninth Widow, all these established concepts and ideas have been suspended and request further examination. Labeled as a work of the new historicism (cf. Chen Sihe 2006 and Zhou Shuitao 2006), the novel deals with the 1940s China and depicts in detail the life changes of a woman from her teens to her fifties. The following section explores the image of the protagonist, a young woman both complimented and censured, the historical perspective embodied by the figure, as well as the politics of the author's writing.

\section{1. "The Alternating Legs" - the History in the Eyes of a Woman}

In the eyes of Putao (葡萄, which literally means “grape”), the female protagonist of the novel, history, especially the period of Chinese history from the anti-Japanese war (1937-1945) to the establishment of the People's Republic of China (PRC) in 1949, is "the alternating legs" outside of their closed gate.

In the 1940s, as a harum-scarum teenager, she often got down on her knees, peeping through the crack of their closed gate. “外头腿都满了 (The outside are all legs)" (Yan 2006a: 16, 17). This is what she usually reported to her father-in-law. She had no idea of the difference between the Kuomintang army, the Japanese troops, the local forces, the civil corps, and the Communist army. The only distinction she observed was the color of their puttees, sometimes in grey and sometimes in yellow; in her heart of hearts, however, all these legs were the same and they were merely brief visitors, or even worse, the intruders or invaders, to the town.

Putao's point of view may sound strange to readers of the present time, but during the many years of war in China, when "a batch of soldiers fights off the other batch, and several days later, another batch fights back and becomes the occupier of the place (一拨人把另一拨人打跑了, 再过两天, 又一拨人

3 All English translations of the novel quoted in this article are done by the author of this essay except where indicated otherwise. 
打回来, 成了占领军),” the civilians, especially the grass-level masses in the countryside, knew little about the political situation of the country (Yan 2006a: 17). It is quite plausible, therefore, that in the eyes of Putao, the history of the town is a series of farces of "hit and run." She was not intelligent enough to tell the justice of the war, and her simple standard of judging the various troops was whether the soldiers were neatly dressed and whether they sponged from or looted the local residents.

As a matter of fact, Putao is not the only one who thinks in this manner. Upon the public denunciation of the landlords, an old townsman, named Shi San-ye (史三爷), expressed his deep concern:

I am old and I have seen a lot. Isn't it a fact that you come and I go, I go and you come again? Nobody takes root in this town. (Yan 2006a: 46-47)

Years later, after she lived through the anti-Japanese war and the three years' civil war, as well as the various campaigns following the establishment of the PRC, Putao concludes, "Nobody [i.e. the outsiders of the town] stays here for long (谁都耽不长)” (Yan 2006a: 218). Her testimony is abundant:

In the past, No. 14 troop ${ }^{4}$ came, stationed, and left. The Eighth Route Army ${ }^{5}$ came and left. The Land Reform Work Team came and stayed for a year, and finally left. ... In the end, what remains is still this village, this group of people, doing the same things: farming, going to the fairs, and strolling around the street. (Yan 2006a: 219)

To put it simply, Putao firmly believes that the non-local-accent speakers, the forces from the outside world, would not remain for long, and the history of the town is a series of farces of fighting against each other. As she said to comfort Lao $\mathrm{Pu}$ (老朴), the out-of-luck writer who was sent down to labor in the village:

It happens a lot. They get different persons to accuse and denounce. The one on the stage may become an audience while the one among the audience may be taken to the stage. [...] Several days later, you might become an audience. You can also put up your fists and shout whatever slogans. (Yan 2006a: 234-235)

\footnotetext{
4 The designation of the Kuomintang army, who came to the town to accept the surrender of the Japanese troops.

5 The designation of the armed forces led by the Chinese Communist Party during the anti-Japanese war, which was combined with other military units to form the PLA at the beginning of the civil war (from 1946 to 1949).
} 
The stage was the same; the difference was the central figure, which changed from time to time.

Based exactly on this logic, Putao developed, by instinct, a kind of practical strategy or philosophy of life during the years of turbulence, which is to hide whenever disaster comes. She even imparted her experience to the younger generation during the 1980s, "Go and hide. Though there is a saying that the monk can be hidden, but not the temple, the fact is we do not have a temple (躲 吧。说是躲得了和尚躲不了庙, 可咱没有庙)” (Yan 2006a: 301). The living witness that proves the success of her philosophy is her father-in-law.

Her father-in-law, Sun Huaiqing (孙怀清), a rich and influential landlord operating a family workshop, was publicly denounced upon the entrance of the PLA work team as a despotic landlord-cum-puppet-leader of the town during the Kuomintang Regime. At the end of the Land Reform Movement, he was shot, but managed to stay alive by sheer luck, among the hundreds of "reactionary" elements. Risking her neck, Putao carried off his dying body from the execution ground under cover of darkness and later hid him in a sweet-potato cellar. The hiding lasted until the late 1970s when the Central Committee of the Chinese Communist Party began to admit and try to put right their left-leaning errors committed during the Land Reform Movement.

Noticeably, Putao's simple view of history is reminiscent of Master Zhu's (朱先生) unique perspective of the fierce power struggles on the White Deer Plain in Chen Zhongshi's fiction. After the abdication of the last emperor in 1912, the White Deer Plain witnessed a round of highly frequent regime changes and coups d'état. First came a group of privates nicknamed by the villagers the “Crow Soldiers" (乌鸦兵, soldiers in black and with white puttees); later on the stage was the “snowstorm” (风搅雪) initiated by the "Peasant Association” (农 协 ${ }^{6}$ under the leadership of the local Communist Party branch; immediately following that was the "Home-returning Legions" (还乡团). ? The "Crow Soldiers" intimidated the peasants to hand in extra grain levies; the "Peasant Association" not only forced open the ancestral hall, smashed the stone plate, on which “乡约” (xiāngyuē, rules and regulations valid for all the inhabitants of a township) had been engraved, but also denounced publicly the local landlords and squires; and when the "Home-returning Legions" came, they launched a vigorous counterblow, arresting the leaders of the "Peasant Association."

6 "Peasant Association" refers to the power organization led by the Chinese Communist Party during the Democratic Revolution in the 1920s, 1930s and 1940s.

7 "Home-returning Legions" refers to the armed bands formed of landlords and local tyrants who fled from the Liberated Areas to the Kuomintang areas during the People's War of Liberation in the 1930s and 1940s. 
GUO

Seeing the continued contests between different political forces, Master Zhu sighed, “The White Deer Plain has been changed into a griddle (白鹿原 这下变成鏊子啦),” to imply the harsh reality that the lasting power struggle among the forces of the Communist, Nationalist and the local non-regular bandits was putting the mass civilians in a very awkward situation (Chen 1993: 254). Like pancakes fried on the griddle, the common people did not know when their bad luck would come and what would happen the next day. To survive, they had to listen to whoever was in office and hand in tax grains apportioned to them under various names.

The alternating legs in Putao's village are tantamount to the changing hands holding the "griddle" of the White Deer Plain. As a matter of fact, in the first half of the twentieth century, the whole China was a "griddle," on which one tragedy after another was enacted. All the initiators believed that they were justified and that they were fighting for the benefits and interests of the people. Rarely did they realize that they were actually sinners committing crimes against their fellow villagers or townsmen.

Similar to Master Zhu's analogy of the griddle, which had been attacked by several critics (cf. Chen Yong 1998), Putao's view of history, or to a certain extent, the author's historical perspective, has led to the critique of "historical nihilism" reflected in the novel. Zhou Shuitao points out that the history in Putao's eyes is repeated and cycled, as is against the social theory that history has its own route and its own motivation (Zhou Shuitao 2006: 82). He further asserts that all works labeled as new historical writings in China, including The Ninth Widow, display a kind of bias against, or absence of, the "right" perspective of historical development. Obviously, for this critic, the "right" perspective of historical development is the Marxist-Leninist teaching dominant in mainland China, that the masses are the promoting forces of history, and that the radical behavior or, to put it a different way, the fierce class struggle between the peasants and the landlords during the Land Reform Movement is understandable and should not be censured. For this critic, the series of revolutionary and political events in the past have promoted the social development of China, and their progressive significance should not be denied or underestimated.

Literary works are products of the authors' reflection about a period of time or a particular event. In many cases, especially under the high-handed political persecution, however, literary productions will be more often than not influenced by the dominating ideology of the times. This is exactly true of literary production under the Chinese Communist Party. Chairman Mao, who governed from 1949 to 1976 , proposed in the early 1940s that literature and 
arts should serve the workers, peasants, soldiers and urban petty bourgeoisie, and this teaching evolved later into the political dogma, "Literature and arts should serve politics" (Mao 1971: 811-813; Zhou Yang 1984: 526). For this reason, the central themes of literary works produced at that time are almost all in compliance with the guiding lines and policies of the Party. After the end of these political movements, many works that had been highly praised before were dumped out of the forum of literary study, and even the authors themselves regret their works, following the wind. In this regard, the contemporary writer Hao Ran (1932-2008), as well as his works, can be taken as a typical example.

Widely known for his Sunny Days (1972) and The Golden Road (1972) in mainland China, Hao Ran was the only author who published novels during the Cultural Revolution. His work, Sunny Days, was praised by Jiang Qing, the wife of Chairman Mao, and he was assigned several times to write according to her wishes. After the end of the Cultural Revolution, however, his works, as well as himself, were attacked fiercely. Bai Ye, a critic of contemporary Chinese literature, concludes that Hao Ran, as a landmark of the Cultural Revolution, is a tragedy, who could have become more excellent if not for the Cultural Revolution (Chen Xu 2008). Obviously, his tragedy results in his ideological tendency displayed in his works, which is closely attached to the extreme politics of those absurd times.

The appearance of the new historical writings in China since the middle of the 1980s is exactly a proof indicating that writers, or to be exact, conscientious intellectuals, began to reflect seriously on the past events and the master narratives about them. They try to return to what actually occurred in history and reveal the inside story under the cover of historical masks. Chen Zhongshi's writing of White Deer Plain is precisely such an example in this regard. As Wu Geng, a contemporary Chinese critic, points out, White Deer Plain was published at a time when Chinese society was changing rapidly from a planned economy to a market economy; confused and puzzled, many intellectuals were pondering over the direction and the future of the socialist country (Wu Geng 2010: 155). As a matter of fact, Chen Zhongshi's perplexity came much earlier than that. He recollected in his "Note" that one day in the early spring of 1982, late at night, when he was riding back after his work in a village, he thought of the image of Liu Qing, the author he worshiped, as well as his novel, The Builders, which he had read innumerable times; he was startled, almost falling off his bicycle. He writes: 
An enormous question mark lay across my mind. What I am doing in the villages on the Wei River, from the early morning to the late night, is exactly opposite to what Liu Qing had taken up thirty years ago at Chang'an Village, at the foot of Zhongnan Mountain. In the early 1950s, Liu Qing moved with his whole family from Beijing to Shaanxi, and settled down at Chang'an Village, participating personally, as a vice chairman of the county, in the cooperative transformation of agriculture. [...] Thirty years later, in 1982, at the sides of the Wei River, fifty kilometers away from Chang'an, I am dividing the land formerly belonging to the Production Brigade into households, according to the quality of the soil and the number of people in a household. [...] The moment I saw the villagers digging the old dividing dam and planting the new boundary stone, a word occurred to me, which I did not say out loud, that the system of collective ownership in the village, which had been established and consolidated for almost thirty years, has been disintegrated completely. ${ }^{8}$ (Chen Zhongshi 2009: 91)

Certainly, Chen Zhongshi is not the sole person showing this concern. In his novel, Life and Death Are Wearing Me Off (2006), Mo Yan expressed a similar perplexity, a doubt, or in other words, a hidden condemnation. Borrowing from Buddhism the term “轮回” (lún húi, which means a life will transform into another form of life after its death), the writer demonstrates the life trajectory of a peasant named Lan, his family members and the villagers from the 1950s to the 1980s. This novel is also labelled as new historical writing. Since Mo Yan was awarded the Nobel Prize of literature in 2012, this novel has been hailed as a new classic.

Viewed in this sense, the novels labeled as new Chinese historical writings are definitely not fictions without correct historical perspectives; quite on the contrary, their appearance represents a voice questioning the official ideology and a kind of revision of the former master narratives about the history of China.

About the alternating legs, Putao is right but not without some reservations. It is true that none of the outsiders stays for long, but what remains is never the same village. To some extent, these alternating legs constituted intruding forces for the self-contented world of the civil society. Their comparatively orderly life had been violently and rudely interrupted. For Putao, for instance, without the intervention of the land-reform work team, her father-in-law would not be publicly denounced and executed and, therefore, she might have had a totally different life route. As the townsmen pondered,

People in Shitun could have a better life without the coming of people from the outside. Once this army or that troop comes, the peaceful life will come

8 This quotation is translated from Chinese to English by the author of this essay. 
Literature as Conduct: On J. Hillis Miller's Speech-act Theory and Its Application

to an end. [...] The non-locals seemed to come specially to sow discord: they incited them to feud with Sun Huaiqing; instigated them to distribute the property and livestock of the rich; encouraged young girls and boys to say no to the parents-arranged engagement; forced them to make a clean break with the Crippled Tiger and finally drive him to the death in the manure pit. (Yan 2006a: 248-249)

When Comrade $\mathrm{Pu}$, the writer who was transferred to work in the village during the Movement of “Four Clean-ups" (四清), joked about whether Putao would like him to live in her house, she retorted, "When you come, have you ever asked us whether we welcome you or not? (你们来, 问过我们欢迎不欢 迎了吗?)” (Yan 2006a: 219) This sounds like a joke, but truly reflects Putao's complicated mentality towards the reality around her, reluctant but having no alternatives. The guests were not invited, but Putao had no right to refuse. Who would pay attention to the reaction of an ordinary village woman at that time? Their coming only made her life from bad to worse since she had to behave more carefully in case her secret was exposed, so that her father-in-law would not be shot for the second time.

During the extreme famine around 1960, the villagers even missed the grand wedding banquet held by Sun's family for Putao and their third son. They could not help thinking, "If only Er-da [local dialect for the second uncle, here referring to Sun Huaiqing] were alive. He knows how to get food (二大 要活着可好了, 他能有法子弄吃的)” (Yan 2006a: 174). When someone reminded his buddy that Sun was a "despotic landlord," the villagers stared blankly at each other and asked, "What on earth does 'despotic' mean? (到 底 “恶霸” 是个啥哩? )” (Yan 2006a: 174) Ironically but understandably, the villagers do not understand the meaning of “恶霸 (è bà),” but they have sent Sun Huaiqing, the protecting power and their backing during the peaceful time, to the guillotine for this title. In the name of revolution, some of them put up their hands to avenge personal wrongs, while many of them just follow suit to avoid drawing fire to themselves. As for the victim of the mass movement, nobody is responsible. It is just his or her bad luck!

It is exactly in this sense that we argue that the alternating legs are not only the epitome of the village history in the eyes of the woman, but also a symbol of the invasion of outside forces into a self-contained civil society. Before the Communist Party controlled the villages, as many scholars have observed, peasant views of their world were mainly based on local norms, which came from their experiences of everyday life (Madsen 1984: 4-6; qtd. in Su Yang 2006: 127). Such customary morality emphasized intravillage harmony, encouraging villagers to become strongly committed to traditional norms and 
roles that were successful in maintaining the steady state of the village in the past. Compared to traditional morality, communist morality is derived mainly from abstract theoretical doctrines which hold that "one's moral obligations toward another are defined by general norms equally applicable to all persons of a particular category - specifically, a class category” (Su Yang 2006: 127).

Precisely based on the logic of class struggle, the PLA work team initiated the masses to denounce Sun Huaiqing; precisely based on the logic that class status decides relationships amongst people, the PLA work team persuaded Putao not to address Er-da as "Dad"; and based on the logic that the political stand should be steadfast, the officials prevented the villagers from speaking with the sent-down Crippled Tiger. As a result, the harmonious order of the village, which had been based mainly on the Confucian tradition - to be benevolent and upright, was destroyed violently, and hatred rose, though it might be hidden temporarily, among villagers who used to be close and cordial.

The degree of this wilful destruction is beyond calculation. As Master $\mathrm{Xu}$ (徐先生) questioned in White Deer Plain, “Is it possible to restore human beings' morality? (人心还能补缀浑全么? )” when Bai Jiaxuan (白嘉轩), the clan elder, tried to renovate the stone plate, on which “乡约” had been engraved (Chen Zhongshi 1993: 219). Undoubtedly, Master Xu is reasonable. Human morality, like a mirror, once broken, can never be repaired and restored to the way it was before. Chen Zhongshi raised this question, and Yan Geling seems to have put forward the same question, too, to express her concern. To some extent, the alienated characters in the novel, like Cai Hupo (蔡琥珀, one of the eight "heroic widows" who rescued an Eighth Route Army soldier at the cost of her genuine husband's life) and Sun Shaoyong (孙少勇, the second son of the Sun's family, who called his father's name straightforwardly in order to show his estrangement from his landlord family, and wrote to the local government appealing for the execution of his father), are one of the many consequences of intruding forces for the villagers. Master Xu is absolutely correct. To smash a kind of order, or a tradition, can be completed in a minute, but to restore the broken order, particularly, to restore humanity, is never easy. The sharp contrast between Putao, the innocent, and Shaoyong and Hupo, representatives of those who have been changed, and alienated, may provide a glimpse of the sudden break with the convention.

\section{The Simple Woman and the Light of Humanity}

Yan Geling asserts in her lecture that her standard of rights and wrongs has been blurred (Yan 2005: 47). This may sound strange at first hearing, but 
taking account of her more than ten years' residence in the US, it is perfectly plausible. The invisible framework of the concepts that had been enforced and she had accepted was doubted and challenged, and she began to step out of the limit set by her times and experiences in China. The creative-writing education she received at Columbia College must have contributed to her change. When she first heard the legend-like true story about an executed man being hidden in the cellar for storing sweet potatoes for thirty years, she was deeply touched, but did not think of putting the story into her work. During the twenty years after that, however, the story popped up again and again, and she began to believe that the story must have some unknown relationship with her.

Preoccupied with the question of how human values are destroyed by various concepts and ideologies, she began her exploration of the female protagonist. Putao is the final achievement of her commitment of literature "to rescue and promote the destroyed primordial and benign humanity" (Zhou Yupei 2003: 92). She is a green egg who has no political consciousness, no concept of the various terms popping up during the series of political campaigns.

She does not know the meaning of “打老虎 (dă lăohŭ)" (as a matter of fact, few villagers understand the term, but they just follow suit), and therefore she is the only person in the town who speaks with the man suffering for it. She sympathizes with his fate as a crippled man who has to carry water on his shoulder, and helps him draw water from the well. Lao $\mathrm{Hu}$, the crippled, the down-and-out (his original name, Chen Jinyu, 陈金玉, has been forgotten), as a normal man, thinks, "It seems to be true that Putao is unsophisticated. The sophisticated should treat me with disdain (她可不是有点儿不省世事人情? 通人情的现在该对他白眼)” (Yan 2006a: 101). He even wonders why there is such a person without any political awareness. Actually, this is exactly the finest quality of Putao, who is never snobbish. She treats people as they are and never hits a person when he is down. Lao Pu, the out-of-luck writer, chose to go to Shitun when he was attacked since he believed that he would not be hurt beside Putao.

In the book, Putao has affairs with several men, including Shaoyong and the two brothers, Dongxi and Chunxi, who were promoted as high as the communist party secretary of the commune. She is happy about the relationship, and she keeps her heart and body separate. Even when she was forced to

9 A colloquial term for the action during the movement against corruption, waste, and bureaucracy within the Party, government, army and mass organizations from 1951 to 1952. 
GUO

have intercourse with the rascal, who discovered accidentally the secret of her father-in-law and threatened to make it public, she did not feel so disgusted as to hate and be eager to take revenge later. Though with a little reluctance, she felt sympathy for the 50-year-old bachelor and did not torture herself with traditional feudal teaching. If she had been equipped with the concept of "chastity and virginity," definitely she would not have felt easy in this situation.

Putao feels at home whenever she is. She does not trouble herself, nor people around her. The critic, Chen Sihe, highly praises Putao for her universal love and all-embracing generosity, saying that she is the legendary image of the Goddess of the earth who has transcended the shackles of humanity (Yan 2006a: 307-308). In my opinion, however, Putao is not such a lofty figure, and I would not like to glorify her as a Goddess. She fails to accept concepts and ideologies, and therefore she has no necessity to go beyond them. She is only a half-illiterate, simple-minded village woman. She is not contaminated by dominant ideologies, and therefore avoids the extremely malicious behaviors of other human beings during that particular time.

Though the author emphasizes that she is not interested in political issues and has no ambition to achieve anything in this area (Yan 2006b: 5), she is establishing her own historical narratives through the image of her protagonist and the historical perspectives embodied in this figure. The author admits that she would like her female characters to be like Buddhists, with infinite compassion and a merciful mind for the people around them (Cao 2006: par. 1). Putao does show some characteristics of a Buddhist. Her love is universal, even for the sent-down country female youth, who was raped and got pregnant. She gave her some dried persimmon, knowing that she was in need of some food at the last stage of pregnancy. She tried to comfort Hupo, the former secretary of the town, when Hupo was removed from office and publicly denounced, though Hupo never looked up to her and always took her as a typical example of people "lagging behind." At that moment, Putao forgot all the words Hupo once used to criticize her.

\section{Tenet of Writing - the Politics of the Unpolitical}

Yan Geling, the author, mentions in several lectures that her legend-like story is based on a file in the local archives she had heard about in the late 1970s. She said,

I was touched deeply when I heard it, but I had never thought of writing a novel out of it. Twenty years later, however, the story still popped out again and again in my imagination, especially after I went to study in the United States. I 
Literature as Conduct: On J. Hillis Miller's Speech-act Theory and Its Application

pondered over it, believing that I must have some unknown relationship with the story. (Yan 2006b: 4)

She went to the province (Henan, a densely-populated area in the middle of China) where the story happened and even paid a visit to the cellar used to hide the person. "We experienced several decades of serious shortage in the supply, and what we are rich in are stories, various legend-like stories," she wrote on the second cover. The problem is how to make the legend true to the readers.

In response to the accusation that she is reversing the verdict about the Land Reform Movement, she said that, as a woman, "I am not interested in Chinese politics and history, which are not my primary concerns. I am aesthetic, and the history only provides me a background. I am not intending to pass any value judgment about the rights and wrongs of the past" (Yan 2006b: 5).

There is nothing wrong with her highlighting her pursuit of universal humanity, but in order to view it from the tenet, or politics of an author's writing, there must be something beyond that claim. Herbert Read describes at the beginning of his article "the politics of the unpolitical" as "the politics of those who desire to be pure in heart: the politics of men without personal ambition; [...] of those who have always striven, whatever their race or condition, for human values and not for national or sectional interests" (Read 1946: 1), but concludes affirmatively, "to be unpolitical does not mean to be without politics: every attitude that is more than egoistic is to that extent social, and a social attitude is a political attitude" (ibid. 11).

Obviously, the author may pretend to be apolitical, but she must have her own politics even beyond her own recognition. In the novel, a woman without even the slightest sense of political consciousness is highlighted, and this, to some extent, may indicate the author's norms of writing. Compared to Putao, all the other figures who were actively involved in various political movements have changed or pondered over their past experiences. Putao is the only one who never changes - unbelievable but possible, at least, in a literary figure. ${ }^{10}$

Furthermore, without the invasion of the alternating legs, the civil society of the village would change, but definitely would not change as radically and

10 Putao's historical perspective results from her innocence, i.e., her mentality that has not been influenced by the dominant official ideology, which urges her to rescue her fatherin-law at the critical moment and differentiates her from other characters like Hupo and Shaoyong. What supports her and guides her behaviors is simple humanity. In the end, all the people changed, except Putao. This indicates that humanity, instead of the ideology of class struggle, wins, and demonstrates from another angle that the ideology of class struggle, as well as other correlating revolutionary discourses should be censured. 
violently as during the revolution. The revolutionary ideology has hurt and even destroyed completely the ethics of folk life, which could never be reversed. If people can live well only when they are not influenced or dominated by certain ideologies, these ideologies must be something questionable and should be censored.

Noticeably, the author creates a world of dwarfs, a sub-civil society that is usually forgotten by normal-sized people. Thanks to their being ignored, they are able to stand by and keep their integrity. Appearing at the upper reaches of the river every summer, worshipping the temple built for the god of dwarfs, they have the opportunity to witness the slaughter and persecution taking place in the world of normal people.

Significantly, however, it is exactly the group of dwarfs, the handicapped in the eyes of normal-sized people, who take on the role of the redeemer, clearing up the mess. The second year after the execution of her father-in-law, Putao gave birth to a boy. Knowing that Shaoyong, the young father of her son, cannot stand the existence of his father, Putao can only harden her heart, cutting off her connection with Shaoyong and leaving her two-month-old illegitimate son to the dwarfs coming to worship at the temple. Without the hiding of her fatherin-law at home, Putao could have had a happy marriage and her son a happy family.

Similarly, it is Putao, the village woman in great need of enlightenment and education in the eyes of the PLA work team and town cadres, who commits herself to save the innocent. In this sense, the dwarfs and Putao are the same. They seem to be physically or mentally handicapped, but actually take on the role of a saviour.

To conclude, though preoccupied with a commitment to rescue and promote the destroyed primordial and benign humanity, the author spares no effort in highlighting the political unconsciousness of the female protagonist and her happiness beyond the control of various concepts. The politics of the author's writing must have gone beyond that, and therefore, her claim of being apolitical might be a kind of revealing of truth, but more possibly a kind of selfprotection, or negotiation.

\author{
Guo Rong \\ rguo2013@aliyun.com \\ School of Humanities \& Law \\ China University of Mining \& Technology, Beijing \\ 100083 \\ P. R. CHINA
}


Literature as Conduct: On J. Hillis Miller's Speech-act Theory and Its Application

\section{Bibliography}

Austin, J. L. 1975. How to Do Things with Words: The William James Lectures Delivered at Harvard University in 1955. $2^{\text {nd }}$ ed. Eds. J. O. Urmson and Marina Sbisà. Cambridge: Harvard UP.

Bai, Ye (白烨). 2006. 《难以遮蔽的人性光辉一读严歌苓长篇新作〈第九个寡妇〉》 [The Light of Humanity: Reading Yan Geling's The Ninth Widow.] - 《书摘》[Book Summary], 4, 126-127.

Cao, Xueping (曹雪萍). 2006.《严歌苓新小说〈第九个寡妇〉叙说农村史诗》 [Yan Geling's New Fiction The Ninth Widow Depicting the Village Epic.] - 《新京报》

[New Beijing Newspaper], 10.03, http://news.sohu.com/20060310/n242231248. shtml, (08.12.2010).

Chen, Sihe (陈思和). 2006. 《跋语》 [Postscript.] - 《第九个寡妇》 [The Ninth Widow]. Beijing: The Writers, 305-309.

Chen, Xu (陈旭). 2008. 《浩然走完 “金光大道” 是是非非自有後人評說》

[Hao Ran Finishes His 'Golden Road'; Rights and Wrongs are Left for the Later Generations to Evaluate.”] - 《華商報》 [Chinese Business View], 21.02. http://www. doc88.com/p-776893462798.html, (08.12.2010).

Chen, Yong (陈涌). 1998. 《关于陈忠实的创作》 [On Chen Zhongshi's Writing.] 《文学评论》[Literary Review], 5-21.

Chen, Zhongshi (陈忠实). 1993.《白鹿原》[White Deer Plain]. Beijing: People's Literature.

Chen, Zhongshi. 2009.《寻找属于自己的句子:〈白鹿原〉创作手记》 [Looking for One's Own Sentences: Notes on Writing White Deer Plain]. Shanghai: Literature and Arts.

Ding, Ling (丁玲). 1952. 《太阳照在桑干河上》 [The Sun Shines over the Sanggan River]. Beijing: People's Literature.

Gao, Jingping and He Xifan (高静平、何希凡). 2007. 《人性・雌性・传统一严歌苓小说 〈第九个寡妇〉文化心理解读》 [Humanity, Femininity, Tradition: Reading Yan Geling's The Ninth Widow from a Cultural Perspective.] - 《现在语文》 [Modern Chinese], 6, 76-77.

Hao Ran (浩然). 1964. 《艳阳天》[The Sunny Days]. Vol. 1. Beijing: Writers.

Hao Ran. 1966. 《艳阳天》 [The Sunny Days]. Vol. 2 \& 3. Beijing: People's Literatures. Hao Ran. 1972. 《金光大道》 [The Golden Road]. Vol. 1. Beijing: People's Literature.

Hao Ran. 1974. 《金光大道》 [The Golden Road]. Vol. 2. Beijing: People's Literature.

Iser, W. 1978. The Act of Reading: A Theory of Aesthetic Response. Baltimore: Johns Hopkins UP.

Jameson, F. 1981. The Political Unconscious: Narrative as a Socially Symbolic Act. Ithaca, N.Y: Cornell UP.

Liu, Qing (柳青). 1966. 《创业史》 [The Builders]. Beijing: Chinese Youth.

Madsen, R. 1984. Morality and Power in a Chinese Village. Berkeley: U of California P. Mao, Zedong (毛泽东). 1971. 《在延安文艺座谈会上的讲话》 [Talks at the Yan'an Forum on Literature and Art.] - 《毛泽东选集》 [Selected Works of Mao Zedong]. Vol. 3. Beijing: People's, 804-835. 
GUO

Miller, J. H. 2001. Speech Acts in Literature. Stanford: Stanford UP.

Miller, J. H. 2005. Introduction. - Literature as Conduct: Speech Acts in Henry James. New York: Fordham UP, 1-12.

Mo, Yan (莫言). 2006. 《生死疲劳》 [Life and Death Are Wearing Me Off]. Beijing: The Writers.

Read, H. 1946. The Politics of the Unpolitical. - The Politics of the Unpolitical. London: Routledge, 1-12.

Rushdie, S. 1991. Imaginary Homelands. - Imaginary Homelands: Essays and Criticism, 1981-1991. London: Granta, 9-21.

Su, Yang. 2006. The Death of a Landlord: Moral Predicament in Rural China, 19681969. - J. W. Esherick, P. G. Pickowicz, A. G. Walder, eds., The Chinese Cultural Revolution as A History. Stanford: Stanford UP, 124-152.

Wang, Guanhan (王冠含). 2008. 《混沌中的强悍与超脱一〈第九个寡妇〉中王葡萄 形象分析》 [Intrepidity and Detachment under the Cover of Muddle-headedness Analysis of the Character Wang Putao in The Ninth Widow.] - 《江汉大学学报》( 人文科学版) [Journal of Jianghan University (Humanities \& Social Sciences)], 27.2 (April), 63-67.

$\mathrm{Wu}, \mathrm{Geng}$ (仵埂). 2010. 《世纪之变的文化探询一一从陈忠实的〈《白鹿原》创作 手记〉重解〈白鹿原〉》 [An Interpretation of Chen Zhongshi’s Bailu Yuan from His My Notes on Writing Bailu Yuan.] - 《小说评论》 [Novel Review], 151, 155-159.

Yan, Geling (严歌苓). 1996.《主流與邊緣 (代序)》[The Mainstream and the Periphery (Preface).] - 《扶桑》[The Lost Daughter of Happiness]. Taipei: Lianjing, i-iv.

Yan, Geling. 2005. 《十年一觉美国梦》 [Ten Years' Dream of America.] - 《华文文学》

[Taiwan, Hong Kong and Overseas Chinese Literature], 3, 47-48.

Yan, Geling. 2006a. 《第九个寡妇》 [The Ninth Widow]. Beijing: The Writers.

Yan, Geling. 2006b 《王葡萄: 女人是第二性吗? 一一严歌苓与复旦大学学生的对

话》 [Wang Putao: Is Female the Second Sex? - A Dialogue between Yan Geling and the Fudan University Students.] Ed. by Jing Wen. - 《上海文学》 [Shanghai Literature]. 5, 4-7.

Zhao, Shuli (赵树理). 1958. 《三里湾》 [Three Mile Bay]. Beijing: People’s Literature and Arts.

Zhou, Libo (周立波). 1956.《暴风骤雨》[The Hurricane]. $2^{\text {nd }}$ ed. Beijing: People's Literature.

Zhou, Shuitao (周水涛). 2006.《从〈第九个寡妇〉看乡村叙事的历史虚无主义》 [The Historical Nihilism of Village Narratives in The Ninth Widow.] - 《小说评 论》 [Novel Review], 131, 80-83.

Zhou, Yang (周扬). 1984. 《新的人民的文艺》 [“The New People’s Literature.”] 《周扬 文集》 [Collected Works of Zhou Yang]. Vol.1. Beijing: People's, 512-35.

Zhou, Yupei. 2003. The Conceptions of Freedom in Contemporary Chinese and Chinese American Fiction: Gish Jen, Yan Geling, Ha Jin, Maureen F. Mchugh. Diss. Kent State University. 